\title{
PENGARUH SUHU DAN LAMA FERMENTASI KOPI TERHADAP KADAR KAFEIN
}

\section{THE EFFECT OF COFFEE TEMPERATURE AND FERMENTATION TIME ON CAFFEINE CONTENT}

\author{
Henny Poerwanty ${ }^{1)}$, Nildayanti ${ }^{1)}$ \\ 1)Department Budidaya tanaman Perkebunan, Pangkep State Polytechnic of Agriculture, \\ Pangkep, South Sulawesi, Indonesia
}

Korespondensi: hpoerwanty@gmail.com

\begin{abstract}
ABSTRAK
Penelitian ini bertujuan mengetahui pengaruh suhu dan lama Proses fermentasi biji kopi Perlakuan yang digunakan pada fermentasi yaitu suhu $\left(35^{\circ} \mathrm{C}\right.$ dan $\left.45^{\circ} \mathrm{C}\right)$ dan lama fermentasi $(6,12$, dan 18 jam). Proses fermentasi biji kopi dengan penambahan ekstrak nanas. Parameter pengamatan meliputi $\mathrm{pH}$ dan kandungan kafein. . Penelitian ini dirancang dalam percobaan faktorial menggunakan rancangan acak lengkap dengan tiga kali pengulangan dengan metode analisis varians menggunakan Statistic Package for Social Sciene (SPSS). Hasil dari analisis sidik ragam memperlihatkan pengaruh nyata $(\alpha=0,05)$ maka dilakukan uji beda nyata dengan menggunakan uji beda jarak berganda Duncan. Berdasarkan hasil penelitian didapatkan bahwa pada fermentasi biji kopi dengan teknologi ohmic pada suhu $35^{\circ} \mathrm{C}$ dan lama fermentasi $12 \mathrm{jam}$ mendapatkan kadar kafein $(1,6 \%)$ menjadi $(0.047 \%)$ dan pada suhu $35^{\circ} \mathrm{C}$ dan lama fermentasi 12 jam didapatkan nilai $\mathrm{pH}$ (4.81). Sedangkan pada suhu $45^{\circ} \mathrm{C}$ dengan lama fermentasi 6 jam mendapatkan nilai kafein yang tinggi yaitu $(0.147 \%)$ dan pada suhu $45^{\circ} \mathrm{C}$ dengan lama fermentasi 18 jam didapatkan nilai $\mathrm{pH}(5,83)$.
\end{abstract}

Kata kunci: Fermentasi, Kopi, Suhu, ,Waktu, dan Kadar kafein

\section{ABSTRACT}

This study aimed to determine the effect of temperature and duration of the coffee bean fermentation process. The treatment used in the fermentation was the temperatures of $35^{\circ} \mathrm{C}$ dan $45^{\circ} \mathrm{C}$ and fermentation times were 6,12 , and 18 hours. The process of fermentation coffee beans with the addition of pineapple extract. The observation parameters included $\mathrm{pH}$ and caffeine content,. This study was designed in a factorial experiment using a completely randomized design with three repetitions with the method of analysis of variance using the Statistical Package for Social Science (SPSS). If the results of the analysis of variance showed a significant effect $(\alpha=0.05)$, then a significant difference test was carried out using Duncan's multiple distance difference test. The research results indicated that in the fermentation of the coffee beans using Ohmic technology at temperature of $35^{\circ} \mathrm{C}$ and the time fermentation of 12 hours, the caffeine content (1.6\%) became $0.047 \%$, and the temperature of $35^{\circ} \mathrm{C}$ and the time of fermentation was 12 hours had produced $\mathrm{pH}$ of 4.81 , and the temperature of $45^{\circ} \mathrm{C}$ with time 
fermentation of 6 hours, high caffeine value of $0.147 \%$, and at $45^{\circ} \mathrm{C}$ with the time fermentation of 18 hours had produces $\mathrm{pH}$ value of 5.83 .

Keywords: Fermentation, coffee, $\mathrm{pH}$, Temperature, Time and caffeine content,.

\section{PENDAHULUAN}

Kopi merupakan tanaman perkebunan yang memiliki nilai ekonomis yang tinggi. Kopi tidak hanya berperan sebagai sumber devisa tetapi juga sumber penghasilan bagi lebih dari satu setengah juta petani kopi di Indonesia. Keberhasilan agribisnis kopi membutuhkan dukungan semua pihak yang terkait dalam proses produksi, pengolahan dan pemasaran komoditas kopi. Upaya meningkatkan produktivitas dan mutu kopi terus dilakukan agar Indonesia dapat bersaing di pasar dunia (Rahardjo, 2012)

Posisi Indonesia dinilai cukup strategis dalam sektor perkopian Internasional, karena Indonesia merupakan Negara pengekspor kopi terbesar ketiga setelah Brazil dan Vietnam (FAO, 2013). Produktivitas kopi Indonesia dari tahun 1980-2017 sebesar 637.539 ton per tahun. Jika pada tahun 1980 volume ekspor kopi Indonesia sebesar 238.677 ton dengan nilai ekspor sebesar US\$ 656 juta, maka tahun 2015 volume ekspor meningkat menjadi 502.021 ton atau senilai US\$1.198 juta (Dirjen Perkebunan, 2016)

Kopi diolah dengan beberapa cara pengolahan yaitu cara basah dan cara kering. Salah satu tahapan pengolahan cara basah kopi arabika yang sangat menentukan mutu adalah fermentasi. Fermentasi bertujuan untuk menghilangkan lapisan lendir yang tersisa di permukaan kulit tanduk biji kopi setelah proses pengupasan. Akan tetapi, proses fermentasi yang terlalu lama akan menghasilkan kopi beras yang berbau apek karena terjadi pemecahan komponen isi lembaga (Ciptadi \& Nasution, 1985).

Bagian terpenting dari lapisan lendir adalah komponen protopektin. Dimana protopektin adalah suatu material kompleks yang tidak larut dari daging buah. Material inilah yang terpecah dalam proses fermentasi. Menurut Ciptadi \& Nasution (1985), terjadinya pemecahan lendir adalah sebagai akibat bekerjanya suatu enzim yang terdapat dalam buah kopi. Enzim ini termasuk jenis katalase yang akan memecah protopektin dalam buah kopi. Selain itu, dalam proses fermentasi juga terjadi pemecahan gula. Hasil dari proses pemecahan gula adalah asam laktat dan asam asetat dengan kadar asam laktat yang lebih besar (Ciptadi \& Nasution, 1985).

Proses fermentasi dapat memacu terjadinya proses kimiawi yang sangat berguna dalam pembentukan precursor citarasa biji kopi yaitu asam organik, asam amino, dan gula reduksi (Lin, 2010). Penanganan kopi secara basah dapat menghasilkan citarasa yang lebih baik 
dengan penanganan kopi secara kering (Murthy \& Naidu, 2011; Subedi, 2011). Pengendalian lama fermentasi harus dilakukan secara akurat untuk mencegah terjadinya over-fermented dan cacat citarasa masa (Schutgens, 2010).

Proses fermentasi yang dilakukan dalam penelitian menggunakan penambahan enzim bromelin yang berasal dari Nanas (Ananas comosus L. Merr). Enzim ini mampu mempercepat proses pelepasan lendir dan memecahkan senyawa protein dan gel serta mampu menurunkan kadar kafein kopi menjadi lebih rendah (Oktadina et al., 2013).

Mengacu pada uraian diatas maka perlu diadakan penelitian mengenai proses fermentasi dengan parameter perlakuan yang perlu dipelajari meliputi lama dan suhu fermentasi serta pengaruhnya terhadap kadar kafein kopi.

\section{METODE}

Kegiatan utama dalam penelitian ini yaitu melakukan fermentasi biji kopi dengan penambahan ekstrak nenas dengan dua faktor pengamatan yaitu lama fermentasi $(6,12,18$ jam) dan suhu $\left(35^{\circ} \mathrm{C}\right.$ dan $\left.45^{\circ} \mathrm{C}\right)$. Tahap kedua penelitian ini dirancang dalam percobaan faktorial menggunakan rancangan acak lengkap dengan tiga kali pengulangan. Penelitian ini dirancang dalam percobaan faktorial menggunakan rancangan acak lengkap dengan tiga kali pengulangan dengan metode analisis varians menggunakan Statistic Package for Social Sciene (SPSS). Hasil dari analisis sidik ragam memperlihatkan pengaruh nyata $(\alpha=0,05)$ maka dilakukan uji beda nyata dengan menggunakan uji beda jarak berganda Duncan.

Analisis Kafein dengan menggunakan metode titrasi Bailey-Andrew dilakukan dengan menimbang 5gr sampel halus (30 mesh) ke dalam erlenmeyer masukkan 5 gr MgO ditambah $200 \mathrm{ml}$ aquades. Pasang pendingin balik, didihkan pelan-pelan selama 2 jam lalu didinginkan kemudian diencerkan sebanyak $500 \mathrm{ml}$ lalu disaring. Dipindahkan filtrat $300 \mathrm{ml}$ ke labu godog ditambah $10 \mathrm{ml}$ asam sulfat (1:9) kemudian di didihkan sampai volume tinggal $100 \mathrm{ml}$. Cairan dimasukkan corong pemisah dan dikocok berkali-kali dengan chloroform berurutan menggunakan 25, 20, 15, 10, 10, dan 10 ml. Semua cairan dimasukkan ke corong pemisah, kemudian ditambah $5 \mathrm{ml} \mathrm{KOH} \mathrm{1 \%} \mathrm{dikocok} \mathrm{dan} \mathrm{dibiarkan} \mathrm{sampai} \mathrm{cairan} \mathrm{terpisah.} \mathrm{Cairan} \mathrm{bagian}$ bawah dikeluarkan kedalam erlenmeyer. Corong pemisah ditambah lagi $10 \mathrm{ml}$ chloroform lalu dikocok biarkan sampai terpisah jelas kemudian cairan bagian bawah dikeluarkan. Larutan dalam chloroform di dalam erlenmeyer diuapkan pada waterbath hingga tersisa residu. Kemudian dikeringkan dalam oven $100^{\circ} \mathrm{C}$ sampai bobot konstan . 


\section{HASIL DAN PEMBAHASAN}

\section{Hasil}

Hasil pengujian kadar kafein dan analisis statistika pada kopi yang difermentasi terlihat pada Tabel 1 dibawah ini.

Tabel 1 Rata-rata kadar kafein fermentasi kopi pada berbagai Lama fermentasi

\begin{tabular}{ccccc}
\hline \multirow{2}{*}{ NO } & Lama & Rata-rata Kadar kafein & \multicolumn{2}{c}{ Nilai signifikan* } \\
\cline { 4 - 5 }$(\mathbf{j a m})$ & 6 & 0,10850 & $\alpha<0,05$ & Sig* \\
\hline 1 & 12 & 0,06800 & 0.05 & 0,000 \\
2 & 18 & 0,08150 & & \\
3 &
\end{tabular}

Berdasarkan Tabel 1, pada perlakuan fermentasi selama 6 jam memiliki nilai kadar kafein yang sangat tinggi yaitu $0,10850 \%$ dan fermentasi selama 12 jam memiliki nilai terendah yaitu $0,06800 \%$. Hasil uji analisis varian menunjukkan nilai $\mathrm{p}<0.05$ yang berarti terdapat pengaruh antara perlakuan lama fermentasi dengan kadar kafein.

Tabel 2. Rata-rata kadar kafein fermentasi kopi berbagai suhu fermentasi

\begin{tabular}{|c|c|c|c|c|}
\hline \multirow{2}{*}{ NO } & \multirow{2}{*}{ Suhu $\left({ }^{\circ} \mathbf{C}\right)$} & \multirow{2}{*}{$\begin{array}{c}\text { Rata-rata Kadar kafein } \\
(\%)\end{array}$} & \multicolumn{2}{|c|}{ Nilai signifikan* } \\
\hline & & & $\alpha<0,05$ & Sig* \\
\hline 1 & 35 & 0,07400 & \multirow{2}{*}{0.05} & \multirow{2}{*}{0,000} \\
\hline 2 & 45 & 0,09800 & & \\
\hline
\end{tabular}

Berdasarkan tabel 2 pada perlakuan fermentasi dengan suhu $35^{\circ} \mathrm{C}$ memiliki nilai kadar kafein yang sangat rendah yaitu $0,07400 \%$ dan fermentasi dengan suhu $45^{\circ} \mathrm{C}$ memiliki nilai kadar kafein yang sangat tinggi yaitu 0,09800 \%. Dengan demikian interaksi antara waktu dan suhu selama fermentasi berpengaruh signifikan $(0,00<0,05)$ terhadap kadar kafein. Hasil penelitian ini menunjukkan bahwa kadar kafein pada perlakuan kopi yang difermentasi mengalami penurunan kadar kafein. Menurunnya kandungan kafein di dalam kopi dikarenakan adanya pengaruh enzim dari nanas. Spesifikasi enzim bromelin pada nanas terdapat substratnya teramat tinggi dalam mempercepat reaksi kimia tanpa produk samping (Lehninger, 1993). 


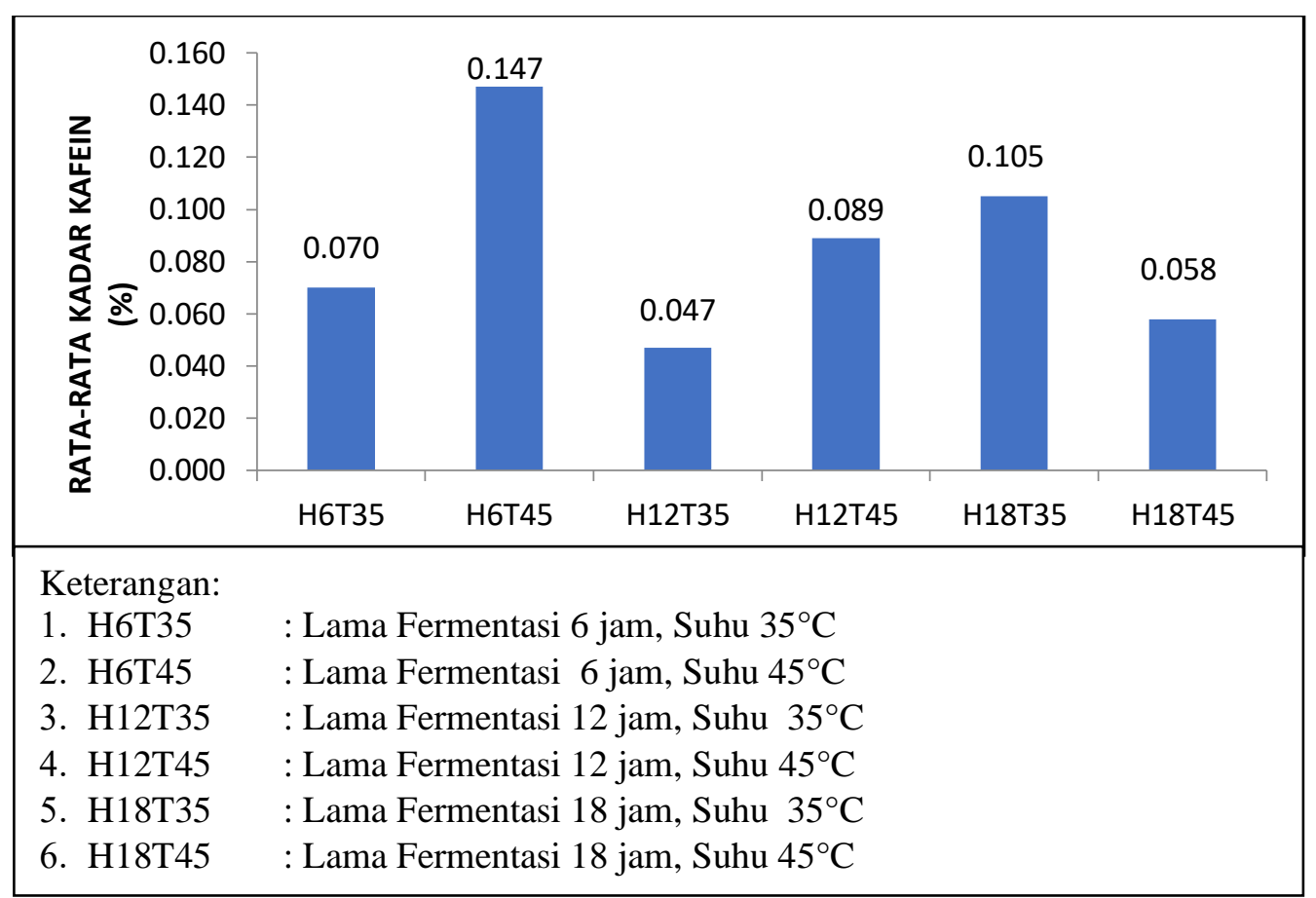

Gambar 1. Pengaruh lama dan suhu fermentasi terhadap kadar kafein

Pada penelitian ini mengalami penurunan kadar kafein. Hal ini terlihat pada Gambar 1 dimana pada fermentasi selama 6 jam dengan suhu $45^{\circ} \mathrm{C}$ memiliki rata-rata nilai kadar kafein yang sangat tinggi yaitu $0,147 \%$ sedangkan pada proses fermentasi selama 12 jam dengan suhu $35^{\circ} \mathrm{C}$ memiliki rata-rata nilai kadar kafein yang sangat rendah yaitu $0,047 \%$.

\section{Pembahasan}

Kafein merupakan senyawa alkaloidxantina berbentuk Kristal dan berasa pahit yang bekerja sebagai obat penenang psikoaktif dan diuretic ringan. Kafein dijumpai secara alami bahan pangan seperti biji kopi, daun teh dan mate. Biji kopi mengandung kafein lebih banyak yaitu 1,6\% - 2,4\% (Clarke \& Macrae, 1985). Penurunan kadar kafein (dekafeinasi) dengan cara sederhana dapat dilakukan dengan memanfaatkan enzim yang bersifat preteolitik seperti bromelin. Pada penelitian ini mengalami penurunan kadar kafein. Hal ini terlihat pada Gambar 1 dimana pada fermentasi selama 6 jam dengan suhu $45^{\circ} \mathrm{C}$ memiliki rata-rata nilai kadar kafein yang sangat tinggi yaitu $0,147 \%$ sedangkan pada proses fermentasi selama 12 jam dengan suhu $35^{\circ} \mathrm{C}$ memiliki rata-rata nilai kadar kafein yang sangat rendah yaitu $0,047 \%$. Hal ini sesuai dengan Lehninger (1993) bahwa enzim bromelin mampu menurunkan nilai kadar kafein sehingga dapat digunakan untuk menghidrolisis protein dan menggumpalkan susu. Bromelin yang terkandung pada buah nanas mampu menghancurkan sejenis protein dan menghambat pembentukan gel untuk gelatin. Sedangkan kafein memiliki sifat yang mirip dengan protein. 
Protein yang terdapat dalam biji kopi mengandung beberapa asam amino yaitu asam aspartat, asparagin, glutamat, prolin, glisin, alanin, valin, tirosin, venilalanin, lisin, histidin, arginin, dan $\gamma$-aminobutirat. Sedangkan isolisin, lisin, valin, venilalanin dan tirosin merupakan asam amino pembentuk rasa tidak sedap pada kopi dan diketopaperezin merupakan protein yang dibentuk oleh asam amino glisin yang membentuk rasa pahit pada kopi (Marcone, 2004).

Kopi dengan rendah kafein selain menghasilkan citarasa dan aroma yang baik juga lebih baik dikonsumsi karena dengan mengkonsumsi kopi rendah kafein akan dapat menstimulasi sistem saraf, sehingga akan memperbaiki mood dan menghalau rasa lelah. Sebaliknya dengan dosis tinggi akan mengakibatkan insomnia, nervous, meningkatkan detak jantung dan tekanan darah (Oktadina et al., 2013). Kafein sering digunakan sebagai perangsang kerja jantung dan meningkatkan produksi urin. Dalam dosis yang rendah kafein dapat berfungsi sebagai bahan pembangkit stamina dan penghilang rasa sakit. Mekanisme kerja kafein dalam tubuh adalah menyaingi fungsi adenosin (salah satu senyawa yang dalam sel otak bisa membuat orang cepat tertidur). Kafein itu tidak memperlambat gerak sel-sel tubuh, melainkan kafein akan membalikkan semua kerja adenosin sehingga menghilangkan rasa kantuk, dan memunculkan perasaan segar, sedikit gembira, mata terbuka lebar, jantung berdetak lebih kencang, tekanan darah naik, otot-otot berkontraksi dan hati akan melepas gula ke aliran darah yang akan membentuk energi ekstra

\section{KESIMPULAN}

Berdasarkan penelitian yang telah dilakukan bahwa fermentasi biji kopi yang dilakukan dengan suhu $35^{\circ} \mathrm{C}$ selama 12 jam memberikan hasil yang terbaik yaitu mampu menurunkan kafein $(1,6 \%)$ menjadi $(0.047 \%)$ dan mendapatkan nilai $\mathrm{pH} 4.81$.

\section{DAFTAR PUSTAKA}

Ciptadi, W., \& Nasution, M. Z. (1985). Pengolahan Kopi. Agro Industri Press, Bogor.

Clarke, R. J., \& Macrae, R. (1985). Coffee, Volume I : Chemistry. Elsevier Applied Science Publishers, London.

Dirjen Perkebunan. (2016). Statistik Perkebunan Indonesia Kopi 2015-2017.

FAO. (2013). http://faostat.fao.org [terhubung berkala].

Lehninger, A. L. (1993). Dasar-dasar Bioimia. Terjemahan Maggy Thenawijaya (Jilid I). Penerbit Erlangga, Jakarta. 
Lin, C. C. (2010). Approach of Improving Coffee Industry in Taiwan Promote quality of Coffee bean by fermentation. The Journal of Internasional Management Studies, 5(1), 154-159.

Marcone. (2004). Kopi, Budidaya dan Penanganan Lepas Panen. PT. Penebar Swadaya. Jakarta.

Murthy, P. \& Naidu, M. M. (2011). Improvement of robusta Coffee fermentation with microbial enzyme. European Journal of Applired Sciences, 3(4), 130-139.

Oktadina, F. D., Argo, B. D., \& Hermanto, M. . (2013). Pemanfaatan Nanas (Annanas Comosus L. Merr) untuk Penurunan Kadar Kafein dan Perbaikan Cita Rasa Kopi (Coffea sp) dalam Pembuatan Kopi Bubuk. Jurnal Keteknikan Pertanian Tropis Dan Biosistem, 1(3).

Rahardjo, P. (2012). Panduan Budi Daya dan Pengolahan Kopi Arabika dan Robusta (Q. Trias (ed.)). Penerbar Swadaya. Jakarta.

Subedi, R. . (2011). Comparative analysis of dry and wet processing of coffee with respect to quality and cost in Kavre Discrict, Nepal: A case of Panchkhal village. Internasional Research Journal of Applied and Basic Sciences, 2(5), 181-183. 